\title{
The effect of the population-based cervical cancer screening program on 5-year survival in cervical cancer patients in Lower Silesia
}

\author{
Dominika Zielecka-Dębska1,5,A-E, Jerzy Błaszczyk ${ }^{2, A, B, D, D}$, , Dawid Błaszczyk ${ }^{3, B, C, E}$, \\ Jolanta Szelachowska ${ }^{1,5, C-E}$, Krystian Lichon' ${ }^{1,5, A, B, D, E}$, Adam Maciejczyk ${ }^{1,5, D, E}$, Rafał Matkowski ${ }^{4,5, A, D-F}$ \\ ${ }^{1}$ Radiotherapy Department, Lower Silesian Oncology Centre in Wrocław, Poland \\ 2 Department of Epidemiology and Lower Silesian Cancer Registry, Lower Silesian Oncology Centre in Wrocław, Poland \\ ${ }^{3}$ Lower Silesian Coordinating Center for Preventive Programs, Lower Silesian Oncology Centre in Wrocław, Poland \\ ${ }^{4}$ Breast Unit, Lower Silesian Oncology Centre in Wrocław, Poland \\ ${ }^{5}$ Department of Oncology, Faculty of Medicine, Wroclaw Medical University, Poland \\ A - research concept and design; B - collection and/or assembly of data; C - data analysis and interpretation; \\ $D$ - writing the article; $E$ - critical revision of the article; $F$ - final approval of the article
}

Address for correspondence

Dominika Zielecka-Dębska

E-mail: zielecka.d@gmail.com

\section{Funding sources}

The research project was fully sponsored

by the Ministry of Science and Higher Education

of Poland with grant No. ST.C280.17.010.

Conflict of interest

None declared

Received on April 10, 2019

Reviewed on May 21, 2019

Accepted on May 31, 2019

Published online on October 22, 2019

Cite as

Zielecka-Dębska D, Błaszczyk J, Błaszczyk D, et al. The effect of the population-based cervical cancer screening program on 5-year survival in cervical cancer patients in Lower Silesia. Adv Clin Exp Med. 2019;28(10):1377-1383.

doi:10.17219/acem/109759

DOI

10.17219/acem/109759

Copyright

Copyright by Author(s)

This is an article distributed under the terms of the

Creative Commons Attribution Non-Commercial License

(http://creativecommons.org/licenses/by-nc-nd/4.0/)

\begin{abstract}
Background. Poland is considered among the European countries with an average incidence of cervical cancer (CC; about 3,000-3,500/year) and at the same time with high mortality (5-year survival rate - 55.2\%). For this reason, in 2006 Poland introduced a Population-Based Cervical Cancer Prevention and Early Detection Program addressed to women aged 25-59 years, in which a cytological test is carried out every 3 years.

Objectives. The aim of the study was to assess the changes in the curability of CC patients brought by the introduction of the Screening Program in the Lower Silesian voivodeship and to identify the subpopulation of women for whom activities aimed at increasing adherence rates must be intensified.

Material and methods. The 5-year relative survival in 3,586 CC patients from 2000-2010 registered in the Lower Silesian Cancer Registry was analyzed.

Results. In the Lower Silesian voivodeship, a 55.1\% 5-year survival rate was recorded in 2000-2004 and $70.5 \%$ in 2010. The highest increase in 5-year relative survival rates was found in rural communities (from $53.1 \%$ in $2000-2004$ to $77.7 \%$ in 2010) and in Wrocław (56.8\% and $74.2 \%$, respectively). In the study group, the number of patients with invasive CC (C53) detected in the local stage of the disease increased systematically from $61.5 \%$ in $2000-2004$ to $74.3 \%$ in 2010.

Conclusions. The introduction of the population-based screening program improved the curability rate in CC patients in the Lower Silesian voivodeship. In order to maintain the recent positive trends, further education should be continued, and activities aimed at increasing adherence to screening tests should be intensified, especially in urban-rural communities.
\end{abstract}

Key words: cervical cancer, screening tests, cancer epidemiology 


\section{Introduction}

Epidemiological statistics list Poland as a country with an increased risk of cervical cancer (CC), where incidence and mortality rates are among the highest in the European Union. ${ }^{1,2}$ Cervical cancer accounts for about $6.5 \%$ of all cancers in Polish women; it ranks $6^{\text {th }}$ for incidence and $8^{\text {th }}$ for mortality. ${ }^{3}$ Increased incidence of $\mathrm{CC}$ is observed in women aged over 20 years, and peak incidence falls in the age range of 49-54 years. ${ }^{1}$ The risk of death from CC in low-income populations, including these in Poland, is around 2-4\%. For the above reasons, this issue is of key importance for social and economic stability of Poland. ${ }^{5}$ In 2006, Poland introduced the Population-Based Cervical Cancer Prevention and Early Detection Program addressed to women aged 25-59 years, whose basic aim is to provide women with a possibility to have a cytology test performed every 3 years free of charge. ${ }^{6,7}$ The primary function of cytology screening is to diagnose and treat precancerous lesions and preinvasive cancer, as well as invasive cancer at an early stage, which helps avoid the cancer or ensure effective treatment. ${ }^{5,8,9}$ In highly developed countries such as Finland, Germany or Sweden, where screening tests were introduced back in the 1960s, the mortality rate of CC decreased by over $80 \%{ }^{3,10}$ However, Poland has not managed to reach the optimal percentage of target population adherence, hence CC screening is not fully effective yet. ${ }^{11}$ The fact that women rarely use screening tests offered by the healthcare system signifies women's poor health-related awareness and the lack of effects of educational activities undertaken by the government and healthcare system. ${ }^{12}$

\section{Objectives}

The aim of the present study was to assess the changes in curability (5-year relative survival) of CC patients (C53 - malignant neoplasm of cervix uteri and D06 - carcinoma in situ of cervix uteri according to ICD-10 classification) after introduction of the population-based screening in the Lower Silesian voivodeship, identify the subpopulation of women for whom activities aimed at increasing adherence to screening tests must be intensified and determine whether there is a positive trend in CC curability despite low adherence to the screening tests.

\section{Material and methods}

The 5-year survival rates in 3,586 CC patients (C53 and D06) from 2000-2010 as registered in the Lower Silesian Cancer Registry (LSCR) were analyzed. According to the registry, 271-374 cases were diagnosed annually in the Lower Silesian voivodeship. To exclude the influence of age on 5-year survival, the values of relative survival were calculated based on the life expectancy tables. Statistical calculations were performed using Microsoft Excel 2013 (Microsoft Corp., Armonk, USA) and the $\chi^{2}$ test with the Yates's correction.

Ethical permission was not applied because the work is based on retrospective data from the LSCR. Our research did not have any influence on patient treatment and survival. No non-routine procedures were performed in the study, so consent from the patients was not taken. The data comes from the LSCR, which is a governmental institution.

\section{Results}

The 5-year relative survival rate in CC patients (C53 and D06) in the Lower Silesian voivodeship has been increasing steadily. It increased from $55.1 \%$ in $2000-2004$ to $60.5 \%$ in 2005-2009, and in 2010 it reached 70.8\% (Table 1) ( $\mathrm{p}<0.00001)$. At the same time, the number of cancers diagnosed at the pre-invasive stage (in situ cancers - D06)

Table 1. Five-year survival in cervical cancer patients in the Lower Silesian voivodeship in 2000-2010

\begin{tabular}{|c|c|c|c|c|c|c|c|c|c|c|}
\hline Year & $\begin{array}{c}\text { Number } \\
\text { of C53+D06 } \\
\text { cancers }\end{array}$ & $\begin{array}{l}\text { 5-year } \\
\text { survival }\end{array}$ & $\begin{array}{l}\text { Observed } \\
\text { survival } \\
{[\%]}\end{array}$ & $\begin{array}{c}\text { Relative } \\
\text { survival } \\
{[\%]}\end{array}$ & $\begin{array}{l}\text { Number } \\
\text { of C } 53 \\
\text { cancers }\end{array}$ & $\begin{array}{l}\text { 5-year } \\
\text { survival }\end{array}$ & $\begin{array}{l}\text { Observed } \\
\text { survival } \\
{[\%]}\end{array}$ & $\begin{array}{c}\text { Relative } \\
\text { survival } \\
{[\%]}\end{array}$ & $\begin{array}{l}\text { Number } \\
\text { of D06 } \\
\text { cancers }\end{array}$ & $\%$ \\
\hline 2000 & 311 & 146 & 46.9 & 49.5 & 301 & 138 & 45.8 & 48.3 & 10 & 3.2 \\
\hline 2001 & 341 & 179 & 52.5 & 55.4 & 332 & 171 & 51.5 & 54.4 & 9 & 2.6 \\
\hline 2002 & 282 & 161 & 57.1 & 60.3 & 279 & 158 & 56.6 & 59.7 & 3 & 1.1 \\
\hline 2003 & 271 & 139 & 51.3 & 54.2 & 258 & 127 & 49.2 & 51.9 & 13 & 4.8 \\
\hline 2004 & 313 & 168 & 53.7 & 56.7 & 292 & 150 & 51.4 & 54.3 & 21 & 6.7 \\
\hline 2005 & 314 & 166 & 52.9 & 55.3 & 294 & 148 & 50.3 & 52.6 & 20 & 6.4 \\
\hline 2006 & 326 & 173 & 53.1 & 55.5 & 278 & 128 & 46.0 & 48.1 & 48 & 14.7 \\
\hline 2007 & 338 & 183 & 54.1 & 56.5 & 283 & 132 & 46.6 & 48.7 & 55 & 16.3 \\
\hline 2008 & 374 & 226 & 60.4 & 63.1 & 275 & 129 & 46.9 & 49.0 & 99 & 26.5 \\
\hline 2009 & 357 & 230 & 64.4 & 67.3 & 245 & 121 & 49.4 & 51.6 & 112 & 31.4 \\
\hline 2010 & 359 & 242 & 67.4 & 70.8 & 257 & 144 & 56.0 & 58.8 & 102 & 28.4 \\
\hline
\end{tabular}


increased in a statistically significant manner in the analyzed group of patients ( $\mathrm{p}<0.00001)$, which greatly improved 5-year survival.

In the group of patients diagnosed with pre-invasive (D06) and invasive (C53) cancer, an upward trend in 5-year survival by $1.5 \%$ per year in 2000-2010 was observed (linear trend: $y=1.5 \cdot x+46.8)$. We also found a steady increase in the survival rate in invasive CC (C53) patients by $1 \%$ per year, which is described by the trend $y=0.03 \cdot x+49.8$ (Fig. 1). In the group of patients diagnosed with invasive CC (C53) a linear reduction in the standardized mortality rate was observed in the years 2000-2015 (Fig. 2). ${ }^{13}$ Between 2000 and 2005, in the Lower Silesian voivodeship, an average number of 142 deaths of women due to invasive CC were reported, in 2006-2010 and in 2011-2015 it was 138 and 133, respectively (trend: almost 1 person/year) (Fig. 2).

As the next step, we analyzed the differences in 5-year relative survival rates depending on the patients' residence. The highest increase in relative curability rates was definitely noted in rural communities (from 53.1\% in 20002004 through $61.5 \%$ in $2005-2009$ to $77.7 \%$ in 2010 ) and Wrocław (56.8\%, 64.4\% and 74.2\%, respectively) (Table 2). The reasons for this were both a higher number of preinvasive CC (D06) detected as shown in Table 1 and Table 3 , and a better prognosis for invasive CC (Table 4). Both of these were an expected consequence of screening tests.

In the following years, a steady increase in the number of patients treated at the Lower Silesian Oncology Center

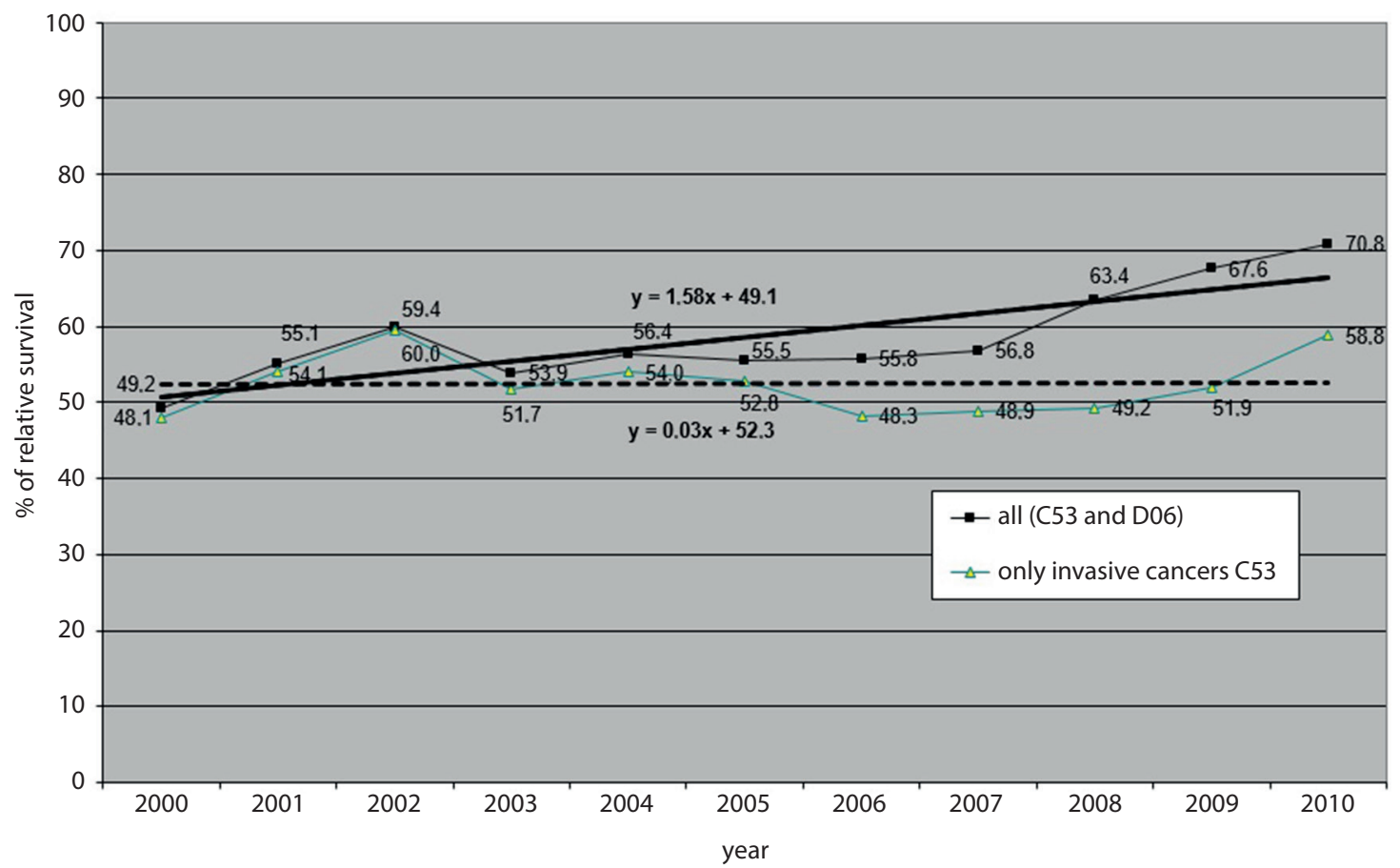

Fig. 1. Five-year relative survival in cervical cancer patients in the Lower Silesian voivodeship in 2000-2010

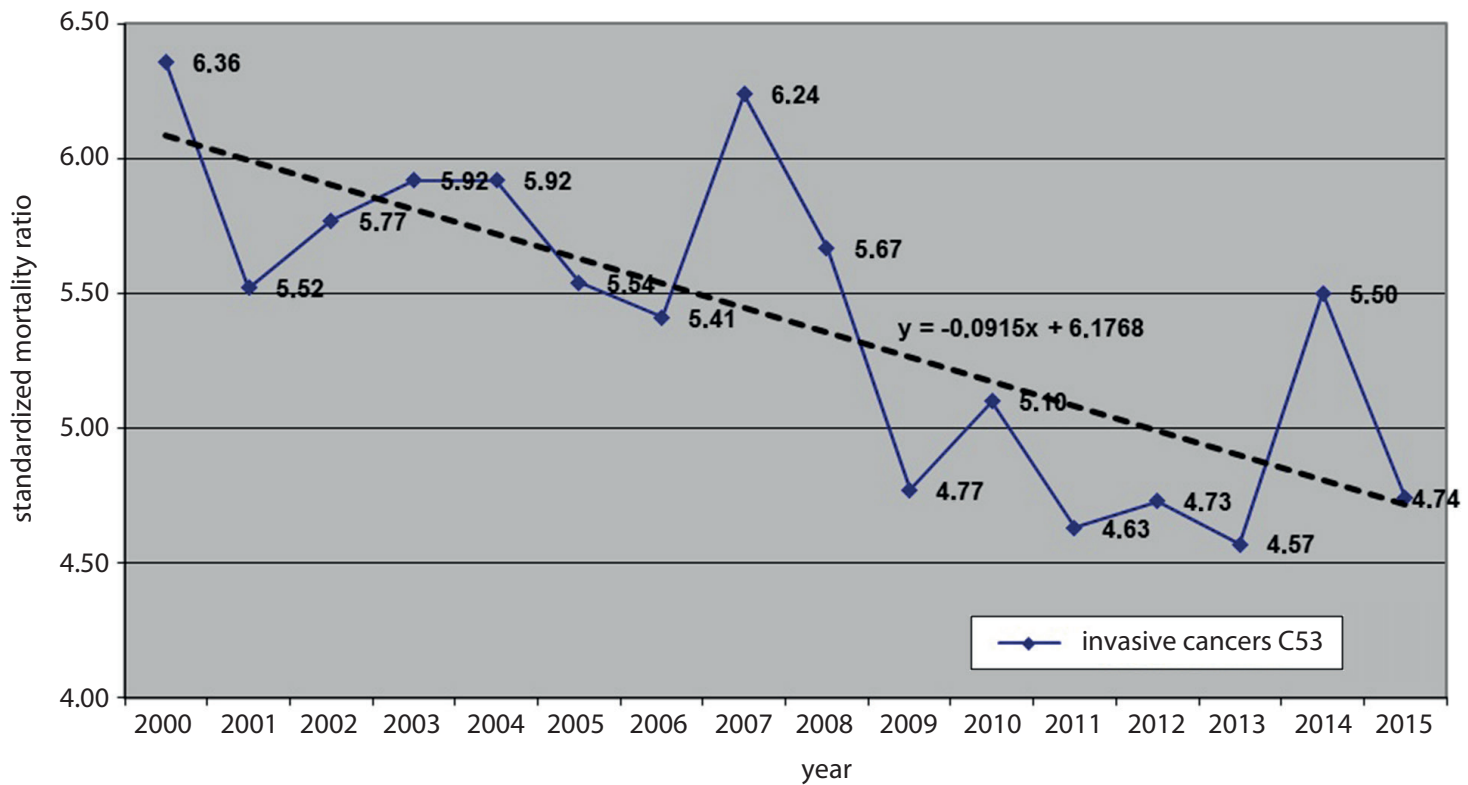

Fig. 2. Standardized mortality rate in invasive cervical cancer patients in the Lower Silesian voivodeship in 2000-2015 ${ }^{13}$ 
Table 2. C53 and D06 (relative) survival by administrative unit

\begin{tabular}{|c|c|c|c|c|c|c|c|c|c|}
\hline \multirow[b]{2}{*}{ Administrative unit } & \multicolumn{3}{|c|}{ 2000-2004 } & \multicolumn{3}{|c|}{ 2005-2009 } & \multicolumn{3}{|c|}{2010} \\
\hline & $\begin{array}{l}\text { number } \\
\text { of cancers }\end{array}$ & $\begin{array}{l}\text { 5-year } \\
\text { survival }\end{array}$ & [\%] & $\begin{array}{l}\text { number } \\
\text { of cancers }\end{array}$ & $\begin{array}{l}\text { 5-year } \\
\text { survival }\end{array}$ & {$[\%]$} & $\begin{array}{l}\text { number } \\
\text { of cancers }\end{array}$ & $\begin{array}{l}\text { 5-year } \\
\text { survival }\end{array}$ & {$[\%]$} \\
\hline Urban community of Wrocław & 321 & 172 & 56.8 & 389 & 236 & 64.4 & 68 & 48 & 74.2 \\
\hline Other urban communities & 560 & 306 & 57.6 & 611 & 327 & 56.7 & 132 & 87 & 68.8 \\
\hline Rural community & 296 & 150 & 53.1 & 293 & 171 & 61.5 & 69 & 52 & 77.7 \\
\hline Town in an urban-rural community & 208 & 95 & 49.0 & 222 & 128 & 60.5 & 43 & 25 & 60.9 \\
\hline Rural area in an urban-rural community & 133 & 70 & 55.4 & 194 & 116 & 63.1 & 47 & 30 & 67.7 \\
\hline
\end{tabular}

Table 3. Incidence of D06 in situ cancers

\begin{tabular}{|c|c|c|c|c|c|c|c|c|c|}
\hline \multirow[b]{2}{*}{ Administrative unit } & \multicolumn{3}{|c|}{$2000-2004$} & \multicolumn{3}{|c|}{$2005-2009$} & \multicolumn{3}{|c|}{2010} \\
\hline & $\begin{array}{c}\text { number } \\
\text { of all } \\
\text { cancers }\end{array}$ & $\begin{array}{c}\text { number } \\
\text { of D06 } \\
\text { cancers }\end{array}$ & [\%] & $\begin{array}{c}\text { number } \\
\text { of all } \\
\text { cancers }\end{array}$ & $\begin{array}{l}\text { number } \\
\text { of D06 } \\
\text { cancers }\end{array}$ & [\%] & $\begin{array}{c}\text { number } \\
\text { of all } \\
\text { cancers }\end{array}$ & $\begin{array}{c}\text { number } \\
\text { of D06 } \\
\text { cancers }\end{array}$ & {$[\%]$} \\
\hline Urban community of Wrocław & 321 & 6 & 1.9 & 389 & 96 & 24.7 & 68 & 17 & 25.0 \\
\hline Other urban communities & 560 & 25 & 4.5 & 611 & 104 & 17.0 & 132 & 40 & 30.3 \\
\hline Rural community & 296 & 11 & 3.7 & 293 & 56 & 19.1 & 69 & 24 & 34.8 \\
\hline Town in an urban-rural community & 208 & 6 & 2.9 & 222 & 35 & 15.8 & 43 & 10 & 23.3 \\
\hline Rural area in an urban-rural community & 133 & 8 & 6.0 & 194 & 43 & 22.2 & 47 & 11 & 23.4 \\
\hline
\end{tabular}

Table 4. Only invasive cancers C53 (relative) survival by administrative unit

\begin{tabular}{|c|c|c|c|c|c|c|c|c|c|}
\hline \multirow[b]{2}{*}{ Administrative unit } & \multicolumn{3}{|c|}{ 2000-2004 } & \multicolumn{3}{|c|}{$2005-2009$} & \multicolumn{3}{|c|}{2010} \\
\hline & $\begin{array}{l}\text { number } \\
\text { of cancers }\end{array}$ & $\begin{array}{l}\text { 5-year } \\
\text { survival }\end{array}$ & [\%] & $\begin{array}{l}\text { number } \\
\text { of cancers }\end{array}$ & $\begin{array}{l}\text { 5-year } \\
\text { survival }\end{array}$ & {$[\%]$} & $\begin{array}{l}\text { number } \\
\text { of cancers }\end{array}$ & $\begin{array}{l}\text { 5-year } \\
\text { survival }\end{array}$ & {$[\%]$} \\
\hline Urban community of Wrocław & 315 & 167 & 56.3 & 293 & 148 & 54.4 & 51 & 32 & 66.8 \\
\hline Other urban communities & 535 & 284 & 56.1 & 507 & 225 & 47.4 & 92 & 48 & 53.3 \\
\hline Rural community & 285 & 141 & 51.9 & 237 & 116 & 52.1 & 45 & 28 & 64.5 \\
\hline Town in an urban-rural community & 202 & 89 & 47.4 & 187 & 94 & 53.1 & 33 & 17 & 54.5 \\
\hline Rural area in an urban-rural community & 125 & 63 & 53.2 & 151 & 75 & 53.1 & 36 & 19 & 56.9 \\
\hline
\end{tabular}

Table 5. Number of patients treated at LSOC by place of residence

\begin{tabular}{|c|c|c|c|c|c|c|}
\hline \multirow[b]{2}{*}{ Administrative unit } & \multicolumn{3}{|c|}{$2005-2009$} & \multicolumn{3}{|c|}{2010} \\
\hline & $\begin{array}{l}\text { number } \\
\text { of cancers }\end{array}$ & $\begin{array}{l}\text { number of patients } \\
\text { treated at LSOC }\end{array}$ & {$[\%]$} & $\begin{array}{l}\text { number } \\
\text { of cancers }\end{array}$ & $\begin{array}{c}\text { number of patients } \\
\text { treated at LSOC }\end{array}$ & {$[\%]$} \\
\hline Urban community of Wrocław & 389 & 212 & 54.5 & 68 & 52 & 76.5 \\
\hline Other urban communities & 611 & 179 & 29.3 & 132 & 63 & 47.7 \\
\hline Rural community & 293 & 127 & 43.3 & 69 & 40 & 58.0 \\
\hline Town in an urban-rural community & 222 & 91 & 41.0 & 43 & 32 & 74.4 \\
\hline Village in an urban-rural community & 194 & 74 & 38.1 & 47 & 31 & 66.0 \\
\hline Total & 1,709 & 683 & 40.0 & 359 & 218 & 60.7 \\
\hline
\end{tabular}

* treated at LSOC by any method, also after surgery performed outside LSOC (but receiving radiotherapy and/or chemotherapy at LSOC); LSOC - Lower Silesian Oncology Center.

in Wrocław (LSOC), which is the referral center for Lower Silesia, was observed. In 2005-2009, 40\% of all CC patients from Lower Silesia were treated at the LSOC, whereas in 2010 this number was as high as $60.7 \%$. Such a large change in the number of patients treated at the LSOC probably resulted from the fact that the patients who had undergone screening were referred for multi-specialist consultation to a full-profile reference center and then received treatment at the LSOC.

Table 5 shows the percentage of patients treated at the LSOC by place of residence. Treatment in the LSOC was most often selected by residents of Wrocław (54.5\% in 2005-2009 and $76.5 \%$ in 2010), while residents of small and medium-sized towns were treated in the LSOC the least frequently $(29.3 \%$ 
Table 6. Five-year (relative) survival, any treatment method, all cancers (C53 and D06)

\begin{tabular}{|l|c|c|c|c|}
\hline \multicolumn{1}{|c|}{ Period } & Treated at LSOC & $\begin{array}{c}\text { 5-year } \\
\text { survival }\end{array}$ & [\%] & $\begin{array}{c}\text { Treated only outside LSOC } \\
\text { survival }\end{array}$ \\
\hline $2005-2009$ & 683 & 463 & 70.8 & 1,026 \\
\hline 2010 & 218 & 141 & 67.5 & 515 \\
\hline
\end{tabular}

LSOC - Lower Silesian Oncology Center.

Table 7. Five-year (relative) survival rates, any treatment used, only invasive cancers (C53)

\begin{tabular}{|l|c|c|c|c|c|}
\hline \multicolumn{1}{|c|}{ Period } & Treated at LSOC & $\begin{array}{c}\text { 5-year } \\
\text { survival }\end{array}$ & [\%] & Treated only outside LSOC \\
\hline $2005-2009$ & 536 & 322 & 63.2 & 839 & 336 \\
\hline 2010 & 175 & 102 & 61.2 & 43.2 \\
\hline
\end{tabular}

LSOC - Lower Silesian Oncology Center.

in 2005-2009 and 47.7\% in 2010), which was most probably due to the fact that municipal hospitals have departments dedicated to the care of gynecology patients.

Another factor that was analyzed was the impact of experience of the hospital center where the patients received treatment on the curability. Firstly, it is worth noting that before 2008 the LSOC was the only entity that provided oncological radiotherapy services in the Lower Silesian voivodeship. Surgical procedures and systemic treatment in the analyzed period were carried out in various centers in the voivodeship, including the LSOC. Out of the 3,586 patients reported to the LSCR, 1,831 had undergone a surgical procedure, radiotherapy was used in 1,915 patients and 1,022 patients received systemic therapy. No treatment was used in 181 (5\%) patients out of the 3,586 patients diagnosed with $\mathrm{CC}$ - these were the patients who were not eligible for treatment due to comorbidities or advanced disease. This data was excluded from the analysis. In the study period, we found a significant increase of the 5-year survival rate in the patients treated outside the LSOC (from $53.5 \%$ to $75.0 \%$ ) (Table 6). This increase was undoubtedly attributed to the higher percentage of in situ cancers (D06) that were detected and treated, as well as a decreasing percentage of patients with invasive CC in this group (C53 accounted for $58.2 \%$ of diagnoses). By contrast, in patients referred to the reference center (LSOC) for treatment, invasive cancers (C53) still accounted for a high percentage of diagnoses (as high as 80.3\%) (Tables 6,7). At the same time, prognosis in patients with invasive $\mathrm{CC}$ (C53) who were treated outside the LSOC remained significantly worse, with 5-year survival of 43.2\% in 2005-2009 and $55.1 \%$ in 2010, whereas in patients treated at the LSOC it was $63.2 \%$ in $2005-2009$ and $61.2 \%$ in 2010 (Table 7). The analysis showed that the treatment results discussed above, namely the 5-year-survival rate in patients with invasive CC (C53) treated outside the LSOC in the study period (2005-2010), were statistically lower $(\mathrm{p}<0.00001)$ than for the patients treated at the LSOC. We observed a systematic increase of the percentage, from $61.5 \%$ in 2000-2004 through $68.7 \%$ in $2005-2009$ to $74.3 \%$ in 2010 , of patients with invasive CC (C53) detected in the local stage of the disease (Table 8).
Table 8. Advancement of invasive cervical cancer (C53)

\begin{tabular}{|l|c|c|c|c|}
\hline Period & $\begin{array}{c}\text { Number and } \\
\text { percentage }\end{array}$ & $\begin{array}{c}\text { Local } \\
\text { disease }\end{array}$ & $\begin{array}{c}\text { Regional } \\
\text { disease }\end{array}$ & $\begin{array}{c}\text { Metastatic } \\
\text { disease }\end{array}$ \\
\hline $2000-$ & $n$ & 643 & 227 & 176 \\
\hline 2004 & $\%$ & 61.5 & 21.7 & 16.8 \\
\hline $2005-$ & $n$ & 748 & 184 & 157 \\
\hline 2009 & $\%$ & 68.7 & 16.9 & 14.4 \\
\hline 2010 & $n$ & 159 & 31 & 24 \\
\hline
\end{tabular}

In 2005-2009 in the Lower Silesian voivodeship, we recorded a $63.2 \%$ 5-year survival rate among patients diagnosed with invasive CC (C53) treated at the LSOC, and a 43.2\% 5 -year survival rate in patients treated outside the LSOC. In this group, $69 \%$ were patients diagnosed with the local stage of the disease, $17 \%$ - with regional stage of the disease and $14 \%$ - with generalized disease (Table 9). According to the $25^{\text {th }}$ Annual FIGO (Fédération internationale de gynécologie et d'obstétrique - International Federation of Gynecology and Obstetrics) Report, in Europe the 5-year survival rate in patients with invasive CC (C53) is $82 \%$ for the local, $42 \%$ for regional and $17 \%$ for generalized stages. ${ }^{14}$ Taking into account the disease advancement data, the expected relative survival rates in patients from our voivodeship can be calculated using the European standard ${ }^{14}: 0.69 \cdot 82 \%+$ $0.17 \cdot 42 \%+0.14 \cdot 17 \%=66.1 \%$.

The above calculations suggest that 5 -year survival rate in the patients receiving treatment at the reference center (LSOC) is at the European level (63.2\%). Unfortunately, a much worse prognosis is observed in the patients treated outside the LSOC (43.2\%).

\section{Discussion}

About 60,000 new cases of CC are diagnosed each year in Europe and as many as half of those patients die. ${ }^{15}$ Largescale studies have shown that screening in women aged 
Table 9. Five-year relative survival (RSC) in 1995-1999 and 2000-200721,22

\begin{tabular}{|c|c|c|c|}
\hline Country & $\begin{array}{c}\text { RSC } \\
1995-1999 \\
{[\%]}\end{array}$ & $\begin{array}{c}\text { RSC } \\
2000-2007 \\
{[\%]}\end{array}$ & $\begin{array}{c}\text { Change } \\
{[\%]}\end{array}$ \\
\hline Northern Europe & 71.6 & 71.5 & -0.1 \\
\hline Denmark & 69.5 & 70.7 & 1.2 \\
\hline Finland & 67.9 & 69.0 & 1.1 \\
\hline Iceland & 76.7 & 84.6 & 7.9 \\
\hline Norway & 72.8 & 75.6 & 2.8 \\
\hline Sweden & 71.0 & 69.9 & -1.1 \\
\hline UK and Ireland & 65.2 & 66.6 & 1.4 \\
\hline Ireland & 65.3 & 66.3 & 1.0 \\
\hline UK (England) & 65.2 & 66.8 & 1.6 \\
\hline UK (Northern Ireland) & 68.6 & 71.8 & 3.2 \\
\hline UK (Scotland) & 67.5 & 66.1 & -1.4 \\
\hline UK (Wales) & 59.3 & 63.1 & 3.8 \\
\hline Central Europe & 69.2 & 68.0 & -1.2 \\
\hline Austria & 67.5 & 68.3 & 0.8 \\
\hline Belgium & 69.3 & 70.2 & 0.9 \\
\hline France & 69.6 & 63.5 & -6.1 \\
\hline Germany & 65.0 & 66.8 & 1.8 \\
\hline Switzerland & 70.6 & 66.7 & -3.9 \\
\hline the Netherlands & 73.2 & 70.3 & -2.9 \\
\hline Southern Europe & 65.3 & 66.9 & 1.6 \\
\hline Croatia & - & 68.0 & - \\
\hline Italy & 65.6 & 66.8 & 1.2 \\
\hline Malta & 64.8 & 54.7 & -11.1 \\
\hline Portugal & 58.0 & 63.8 & 5.8 \\
\hline Slovenia & 71.8 & 75.5 & 3.7 \\
\hline Spain & 66.1 & 66.1 & 0 \\
\hline Eastern Europe & 63.7 & 60.3 & -3.4 \\
\hline Bulgaria & - & 54.8 & - \\
\hline Czech Republic & 72.0 & 67.1 & -4.9 \\
\hline Estonia & - & 65.6 & - \\
\hline Latvia & - & 52.0 & - \\
\hline Lithuania & - & 58.9 & - \\
\hline Poland* & 53.3 & 55.2 & 1.9 \\
\hline Slovakia & 65.8 & 66.5 & 0.7 \\
\hline European average & 64.7 & 65.4 & 0.7 \\
\hline
\end{tabular}

* Lower Silesian and Świętokrzyskie voivodeship as well as city of Kraków participated in the study.

21-65 years with a cytology test significantly reduces the CC incidence and mortality rate. ${ }^{16,17}$ Although widely available, free-of-charge prophylactic cytology tests has been available in Poland for a few years and access to diagnostic tests has become easier, the number of new cases remains high despite the downward trend. ${ }^{18}$ The reason behind the low adherence of the target population to screening cytology tests is low awareness of the benefits of such tests, as well as insufficient knowledge among the target group about the screening tests offered. ${ }^{19,20}$ It should also be underlined that some cases of CC develop despite women's participation in screening (adenocarcinomas), and some of the cases occur in groups not covered by regular screening. ${ }^{15}$ In order to compare the effectiveness of conducted activities aimed at reducing mortality from malignant neoplasms, EUROCARE studies were conducted in Europe. In the EUROCARE-5 study (2000-2007), an average of 65.4\% for 5-year relative survival was obtained, with the highest values found in Northern Europe (71.5\% on average) and Central Europe (68\%), and the lowest values noted in Eastern Europe (60.3\%). ${ }^{21}$ In comparison with survival rates in 1995-1999, no unequivocal increase in survival rates was noted in Europe or in individual countries (Table 9). ${ }^{22}$

The 5-year survival rate in Poland in 2000-2007 (55.2\%) was among the lowest in Europe, being almost 10\% lower than the average for Europe, and almost 30\% lower than the average for Iceland. ${ }^{21}$ In 1995-1999, this rate in Poland was lower by a further $1.9 \%$.

In the Lower Silesian voivodeship in 2000-2004, relative survival was $55.1 \%$, in $2005-2009$ it was $60.5 \%$ and in 2010 it was $70.5 \%$. It is worth noting that if a survival rate of over $70 \%$ is maintained in the following years, the Lower Silesian voivodeship may rank high in the planned EUROCARE- 6 study because only 8 European countries had a rate value of over 70\% (Table 9) in EUROCARE-5. ${ }^{21}$ Considering the upward trend in detecting in situ cancers, an extremely beneficial effect of population-based screening on 5-year survival rate in CC patients is observed (Table 4). The highest increase in the relative curability rates was noted among patients residing in rural communities (from $53.1 \%$ in $2000-2004$ through $61.5 \%$ in $2005-$ 2009 to $77.7 \%$ in 2010) and in Wrocław. While in the case of Wrocław better results may be attributed to easily available cytology test and screening information, the deciding factor in rural communes might have been the provision of free of charge medical service and significantly and gradually rising public awareness regarding cancer prevention. At the same time, it is unclear why such a major effect of screening was not observed in communal towns, i.e., small and medium-sized towns. The higher 5 -year survival rate in CC patients was accompanied by a higher percentage of patients undergoing treatment at the LSOC. In 2010, compared to 2005-2009, the number of patients treated at the LSOC increased by over $20 \%$ from $40 \%$ to $60.7 \%$ of all cancer patients in the Lower Silesian voivodeship. The authors believe that centralized therapy in the center with the most extensive experience in the treatment of CC contributed to better treatment outcomes for the patients.

\section{Conclusions}

The 5-year survival rate in 2000-2007 in Poland (55.2\%) was among the lowest ones in Europe, being almost 10\% lower than the European average. In the Lower Silesian 
voivodeship, a 55.1\% 5-year survival rate was recorded in $2000-2004,60.5 \%$ in $2005-2009$ and $70.5 \%$ in 2010 . The highest increase in relative survival rates was found in rural communities (from 53.1\% in 2000-2004 through $61.5 \%$ in $2005-2009$ to $77.7 \%$ in 2010 ) and in Wrocław $(56.8 \%, 64.4 \%$ and $74.2 \%$, respectively). In the group under study, the number of patients with invasive CC (C53) detected in the local stage of the disease increased systematically from $61.5 \%$ in $2000-2004$ through $68.7 \%$ in $2005-2009$ to $74.3 \%$ in 2010 . Five-year relative survival rates in Lower Silesian patients receiving treatment at the LSOC $(63.2 \%$ and $61.2 \%$ ) were significantly better than those in patients treated in other centers (43.2\% and 55.1\%) and close to the expected relative survival rates for Lower Silesian patients with invasive cancers (66.1\%). In conclusion, the introduction of the population-based screening program improved the curability rate for CC patients in the Lower Silesian voivodeship. However, to ensure that the recent positive trends are continued, women must be educated further, and activities aimed at increasing adherence to screening tests must be intensified, particularly in urban-rural communities. At the same time, patients diagnosed with CC must be systemically referred to highly specialized centers where comprehensive treatment is provided.

\section{ORCID iDs}

Dominika Zielecka-Dębska (1) https://orcid.org/0000-0001-6731-5400 Jerzy Błaszczyk (1) https://orcid.org/0000-0002-9331-9728 Dawid Błaszczyk (1) https://orcid.org/0000-0001-7396-1660 Jolanta Szelachowska (1) https://orcid.org/0000-0003-3254-6625 Krystian Lichoń (1) https://orcid.org/0000-0002-9311-7069 Adam Maciejczyk (10) https://orcid.org/0000-0002-7047-0433 Rafał Matkowski (ㅇ) https://orcid.org/0000-0002-1705-5097

\section{References}

1. Barnaś E, Borowiec-Domka E, Kądziołka J, Grzegorczyk J. Factors affecting the response-rate to cytology examinations of women in the Subcarpathian region, National Programme of Cervical Cancer Prophylaxis [in Polish]. Probl Hig Epidemiol. 2008;89(4):482-486.

2. World Health Organization, Department of Information, Evidence and Research. Mortality database. http://www-dep.iarc.fr/WHOdb/ table2.asp of subordinate document. Accessed March 31, 2019.

3. Nowicki A, Borowa I, Maruszak M. Women health behaviours regarding prevention and early detection of precancerous lesions and cervical carcinoma [in Polish]. Ginekol Pol. 2008;79(12):840-849.

4. Denny L, Kuhn L, De Souza M, Pollack AE, Dupree W, Wright TC Jr. Screen-and-treat approaches for cervical cancer prevention in lowresource settings: A randomized controlled trial. JAMA. 2005;294(17): 2173-2181.

5. Goldie SJ, Gaffikin L, Goldhaber-Fiebert JD, et al; Alliance for Cervical Cancer Prevention Cost Working Group. Cost-effectiveness of cervical-cancer screening in five developing countries. N Engl J Med. 2005;353(20):2158-2168.
6. Mariańczyk K, Steuden S. Expectations and intentions of health behaviours as factors determinating performance of preventive Pap smear among women aged over 45 [in Polish]. Psychoonkologia. 2011; 2:55-64.

7. Nowakowski A, Wojciechowska U, Wieszczy P, Cybulski M, Kamiński MF, Didkowska J. Trends in cervical cancer incidence and mortality in Poland: Is there an impact of the introduction of the organised screening? Eur J Epidemiol. 2017;32(6):529-532.

8. Gustafsson L, Ponten J, Zack M, Adami H-O. International incidence rates of invasive cervical cancer after introduction of cytological screening. Cancer Causes Control. 1997;8(5):755-763.

9. Spaczyński M, Karowicz-Bilinska A, Kędzia W, et al. Costs of Population Cervical Cancer Screening Program in Poland between 20072009 [in Polish]. Ginekol Pol. 2010;81(10):750-756.

10. Anttila A, Pukkala E, Söderman B, Kallio M, Nieminen P, Hakama M. Effect of organised screening on cervical cancer incidence and mortality in Finland, 1963-1995: Recent increase in cervical cancer incidence. Int J Cancer. 1999;83(1):59-65.

11. Zielecka D, Lichoń K, Maciejczyk A, Błaszczyk J, Błaszczyk D, Matkowski R. Wpływ cytologicznych badań przesiewowych na zachorowania na raka szyjki macicy w województwie dolnośląskim w latach 2005-2014. Postepy Hig Med Dosw. 2018;72:13-20.

12. Słopiecka A, Wiraszka G. Women's attitudes towards reproductive system disease prevention. Eur J Clin Invest. 2013;1:50-60.

13. Wojciechowska U, Didkowska J. Zachorowania i zgony na nowotwory złośliwe w Polsce. In: Krajowy Rejestr Nowotworów, Centrum Onkologii - Instytut im. Marii Skłodowskiej-Curie. http://onkologia. org.pl/raporty/of subordinate document. Accessed March 27, 2019.

14. Sergio P. $25^{\text {th }}$ Annual Report on the Results of Treatment of Gynecological Cancer. London, UK: Elsevier Health Sciences; 2003.

15. Spaczyński M, Nowak-Markwitz E, Witold K. Cervical cancer screening in Poland and worldwide [in Polish]. Ginekol Pol. 2007;78(5): 354-360.

16. Moyer VA; U.S. Preventive Services Task Force. Screening for Cervical Cancer: U.S. Preventive Services Task Force Recommendation Statement. Ann Intern Med. 2012;156(12):880-891.

17. Dillner J, Rebolj $M$, Birembaut $P$, et al. Long term predictive values of cytology and human papillomavirus testing in cervical cancer screening: Joint European cohort study. BMJ. 2008;337:1756-1833.

18. Karczmarek-Borowska B, Grądalska-Lampart M. Cervical cancer incidence and mortality rates including the screening program results in the Podkarpackie Region between 1999-2010 [in Polish]. Ginekol Pol. 2013;84(11):930-937.

19. Tuchowska P, Worach-Kardas H, Marcinkowski JT. The most frequent malignant tumors in Poland: The main risk factors and opportunities to optimize preventive measures [in Polish]. Probl Hig Epidemiol. 2013;94(2):166-171.

20. Wrześniewska M, Adamczyk-Gruszka O, Gruszka J, Bąk B. Diagnostic and therapeutic possibilities in the prophylaxis of cervical cancer [in Polish]. Stud Med. 2013;29(1):109-116.

21. Sant M, Chirlaque Lopez MD, Agresti R, et al; EUROCARE-5 Working Group. Survival of women with cancers of breast and genital organs in Europe 1999-2007: Results of the EUROCARE-5 study. Eur J Cancer. 2015;51(15):2191-2205.

22. Berrino F, De Angelis R, Sant M, et al; EUROCARE-4 Working Group. Survival for eight major cancers and all cancers combined for European adults diagnosed in 1995-99: Results of the EUROCARE-4 study. Lancet Oncol. 2007;8(9):773-783. 